\title{
Balesari Culture and Language (BCL) sebagai Katalisator Desa Wana Wisata Balesari
}

\author{
Yulia Esti Katrini, Farikah Faradisa, Imam Baihaqi \\ Universitas Tidar Magelang \\ Email: farikahfaradisa@gmail.com
}

\begin{abstract}
Wana Wisata of Balesari village has huge potential to be developed into a national and even international tourist village. Balesari village is also categorized as a virgin, and it still has many local wisdoms that can be a special attraction for domestic visitors and also foreign tourists if the community of Balesari can manage it properly and maximally.. The focus of the contribution of Tidar University to the community is to serve the community to support the development of rural areas, one of them is Wana Wisata of Balesari Village. The development of villages is focused on Balesari Culture and Language activities that is cultural and linguistic conservation that manifests in awareness of activities, training, and cultural and linguistic assistance to become a tourist icon in Balesari village. In addition gradually over a period of 3 years, Balesari Culture and Language programs will also conserve the culture and language based on local wisdom in the village of Balesari gradually as a catalyst that will participate in improving the development of Balesari Wana Tourism Village.
\end{abstract}

Abstrak: Desa Wana Wisata Balesari memiliki potensi yang sangat besar untuk dapat dikembangkan menjadi sebuah desa wisata bertaraf nasional bahkan internasional. Desa Balesari juga dikategorikan masih perawan, masih terdapat banyak kearifan lokal yang dapat menjadi daya tarik tersendiri bagi para pengunjung domestik apalagi wisatawan asing apabila masyarakat dapat mengelolanya dengan baik, maksimal, dan profesional. Fokus kontribusi Universitas Tidar kepada masyarakat adalah melakukan pengabdian kepada masyarakat untuk mendukung pembangunan wilayah perdesaan salah satunya adalah Desa Wana Wisata Balesari. Pembangunan desa tersebut difokuskan dalam kegiatan Balesari Culture and Language yaitu konservasi budaya dan bahasa yang mewujud dalam kegiatan penyadaran, pelatihan, dan pendampingan budaya dan bahasa agar menjadi ikon wisata di desa Balesari. Selain itu secara bertahap dalam jangka waktu 3 tahun, program Balesari Culture and Language juga akan melakukan konservasi budaya dan bahasa berbasis kearifan lokal yang terdapat di desa Balesari secara bertahap sebagai katalisator yang akan ikut mempercapat laju perkembangan Desa Wana Wisata Balesari.

Kata Kunci: Balesari, Culture and Language, Desa Wana Wisata 


\section{PENDAHULUAN}

Pengabdian merupakan salah satu fungsi dan peran dari perguruan tinggi. Dalam undang-undang nomor 12 tahun 2012 perguruan tinggi diwajibkan melaksanakan tri dharma pendidikan yaitu pendidikan, penelitian, dan pengabdian kepada masyarakat. Pengabdian kepada masyarakat dapat dilaksanakan dalam lingkungan pondok pesantren melalui transfer pengetahuan yang ada di perguruan tinggi. Undang-undang Nomor 6 Tahun 2014 tentang Desa memberikan ruang yang sangat luas untuk pembangunan kawasan perdesaan. Desa diberikan keleluasaan untuk membangun dan mengembangkan segala potensi yang dimiliki. Pemerintah juga mendorong secara penuh dengan menerbitkan Peraturan Pemerintah nomor 43 tahun 2014 dengan asumsi bahwa pembangunan kawasan perdesaan dilaksanakan dalam upaya untuk mempercepat dan meningkatkan kualitas pelayanan, pembangunan, dan permberdayaan masyarakat desa melalui pendekatan pembangunan partisipatif.

Salah satu agenda prioritas pembangunan nasional dalam kabinet kerja adalah pembangunan kawasan perdesaan. Dukungan regulasi dan kelembagaan telah diberlakukan dengan adanya Undang-Undang Nomor 6 Tahun 2014 tentang Desa beserta peraturan teknis yang menyertainya dan kementerian yang khusus menangani sektor pembangunan perdesaan yaitu Kementerian Desa, Pembangunan Daerah Tertinggal dan Transmigrasi. Secara lebih teknis, Peraturan Pemerintah Nomor 43 Tahun 2014 perdesaaan pembangunan mengamanatkan pembangunan kawasan perdesaan dilaksanakan dalam upaya mempercepat dan meningkatkan kualitas pelayanan, pembangunan, dan pemberdayaan masyarakat Desa melalui pendekatan pembangunan partisipatif. Titik berat upaya pengembangan perdesaan diarahkan untuk fasilitasi penyusunan rencana tata ruang kawasan perdesaan secara partisipatif, pengembangan pusat pertumbuhan antar desa secara terpadu, penguatan kapasitas masyarakat, kelembagaan dan kemitraan ekonomi serta pembangunan infrastruktur antar perdesaan.

Desa Balesari merupakan salah satu desa di KecamatanWindusari Kabupaten Magelang yang berbatasan dengan Desa Kembang Kuning pada bagian selatan, desa Windusari pada bagian utara, bukit Giyanti pada sisi barat dan desa Mojo pada sisi timur. Desa Balesari merupakan desa yang berada di lereng Gunung Sumbing dan memiliki panorama alam yang sangat indah. Desa ini memiliki udara yang sejuk sehingga memiliki potensi untuk dijadikan desa wisata. Gayung bersambut dengan hal tersebut, Universitas Tidar melalui Unit Pelaksana Teknis Pengembangan Kewirausahaan dan Pembangunan Pedesaan (UPT PKPP) menjadikan desa Balesari sebagai Desa Wana Wisata yang 
merupakan desa binaan Universitas Tidar yang sudah dikelola sejak tahun 2009. Desa Balesari sebagai desa binaan Universitas Tidar sedang dalam proses pengembangan menjadi desa wana wisata.

Desa wisata merupakan salah satu bentuk penerapan pembangunan pariwisata berbasis masyarakat dan berkelanjutan. Masyarakat lokal berperan penting dalam pengembangan desa wisata karena sumber daya dan keunikan tradisi dan budaya yang melekat pada komunitas tersebut merupakan unsur penggerak utama kegiatan desa wisata (Dewi et al., 2013). Keberhasilan pengembangan desa wisata tergantung pada tingkat penerimaan dan dukungan masyarakat lokal. Pengembangan desa wisata dapat melalui berbagai aspek meliputi pendidikan, pertanian, tata ruang, sosial, dan ekonomi.

Desa Balesari secara administratif terdiri dari dusun Ngemplak, dusun Malanggaten, dusun Jambeyan, dusun Mojo dan dusun Kembangsari. Desa Balesari berada pada ketinggian +450 hingga +1.050 di atas permukaan laut (MDPL) Desa ini memiliki potensi alam, budaya serta sumber daya manusia yang sedang dikembangkan menjadi sebuah desa wisata. Mengusung nama "Puncak Giyanti 0 Kilo Meter Jawa", Universitas Tidar berusaha mengembangkan desa ini menjadi desa wisata yang memiliki kekhasan tersendiri dan mampu menarik wisatawan baik lokal maupun internasional.

Desa Wisata Balesari sekarang sudah mulai dikenal sebagai tempat wisata pendakian gunung atau Wisata Gunung Giyanti. Karang Taruna setempat mulai mempromosikan keindahan pemandangan yang ditawarkan ketika para pendaki sampai ke puncak melalui media sosial, Instagram. Seiring berjalannya waktu, beberapa potensi lain dari Balesari akan mulai dimunculkan dan disatukan dalam kesatuan yang utuh sebagai desa wisata tentunya media promosi dan publikasi juga perlu disesuaikan.

Setelah kesepakatan Earth Summit tahun 1992 di Brazil's Rio de Janeiro, industri pariwisata telah bergeser pada tiga arus utama yaitu menjaga keseimbangan lingkungan hidup, keniscayaan akan edukasi kepariwisataan dan persepsi postif antara tuan rumah dan atau pelancong serta pengembangan sumberdaya manusia. Hal ini juga melahirkan konsep baru penyelenggaraan industri pariwisata dengan pendekatan komunitas. Dalam konsep wisata berbasis komunitas, perlu adanya pelibatan, partisipasi dan sinergitas dengan komunitas lokal.

Perspektif sosial dan budaya serta kondisi eksisting lokus desa wisata menjadi dimensi prima yang perlu dipertimbangkan dalam perencanaan pengembangan wisata. Kultur masyarakat sebagai bagian integral dalam kehidupan bermasyarakat hendaknya mendapat tempat dalam proses 
pengembangan desa wisata tersebut. Local wisdom dan budaya setempat yang dimanifestasikan dalam bentuk seni, adat, dan pertunjukan budaya khas pada lokus penelitian menjadi modalitas yang bisa dijual kepada wisatawan dan menjadi daya tarik desa wisata.

Desa sangat perlu mendapatkan sentuhan akademisi, pelaku bisnis dan pemerintah. Universitas Tidar (UNTIDAR) telah membangun Desa Balesari, Kecamatan Windusari, Kabupaten Magelang Provinsi Jawa Tengah. Sejak tahun 2009, UNTIDAR menanam pohon buah-buahan. Kurang lebih 2000 bibit durian, 500 bibit mangga, 500 bibit rambutan, dll. Pada saat ini, Januari 2016, tanaman itu mulai berbuah. Fenomena bagi masyarakat desa ialah pemasaran buah-buahan. UNTIDAR juga telah membina masyarakat Desa Balesari perihal kerajinan, pertanian, dll. Ini merupakan potensi.

Desa Wana Wisata Balesari memiliki potensi yang sangat besar untuk dapat dikembangkan menjadi sebuah desa wisata bertaraf nasional bahkan internasional. Terdapat 3 pos pendakian dan masing-masing pos terdapat gazebo yang dapat digunakan untuk melihat panorama sekitar. Di gazebo tersebut pengunjung dapat menikmati keindahan gunung sumbing yang dibalut dengan hijaunya pemandangan alam yang akan menambah kenikmatan pandang pada mata dan rasa.

Selain itu desa Balesari juga dikategorikan masih perawan, masih terdapat banyak kearifan lokal dapat menjadi daya tarik tersendiri bagi para pengunjung domestik apalagi wisatawan asing apabila masyarakat dapat mengelolanya dengan baik dan maksimal. Salah satu kearifan lokal tersebut adalah adanya kesenian tari topeng ireng. Tari Topeng Ireng adalah bentuk kesenian rakyat yang berbentuk Tari yang ditarikan secara kelompok hasil budaya masyarakat Jawa yang telah berkembang di tengah masyarakat lereng Merapi-Merbabu sejak bertahun-tahun yang lalu yang berfungsi sebagai hiburan (Pujiyanti, 2013: 2). Masyarakat dapat mengelola kearifan lokal yang dimiliki masyarakat di desa Balesari sehingga kearifan lokal tersebut dapat menjadi magnet yang kuat untuk menarik para wisatawan terutama wisatawan asing yang kian hari kian tertarik pada hal-hal yang berbau kearifan lokal.

Civitas akademika sebagai agen dalam sebuah institusi yang mengemban tridharma perguruan tinggi mempunyai tanggung jawab untuk menyelenggarakan pengabdian kepada masyarakat, kegiatan penelitian, dan kegiatan pendidikan. Fokus kontribusi Universitas Tidar kepada masyarakat adalah melakukan pengabdian kepada masyarakat untuk mendukung pembangunan wilayah perdesaan salah satunya adalah Desa Wana Wisata Balesari. 
Pembangunan desa tersebut difokuskan dalam kegiatan Balesari Culture and Language yaitu konservasi budaya dan bahasa yang mewujud dalam kegiatan penyadaran, pelatihan, dan pendampingan budaya dan bahasa agar menjadi ikon wisata di desa Balesari. hal ini perlu dilakukan karena dunia pariwisata merupakan salahsatu penyumbang devisa terbesar ne- gara, di samping sektor migas. Sebagai sumber pendapatan, maka sudah selayaknya sektor pariwisata mendapat perhatian lebih intensif atau paling tidak sejajar dengan sektor-sektor lain, apalagi penggalian dari dari sektor ini belum dimaksimalkan (Karim, 2010: 147).

Hasil kebudayaan suatu masyarakat dan Benda Cagar Budaya (BCB) banyak dikunjungioleh wisatawan sebagai wisata pendidikan dan wisata budaya. Keduanya ini sarat dengan nilai sejarah, nilai ilmu pengetahuan dan nilai kebudayaan yang harus ditransformasikan dan dilestarikan. Keberadaan dan klasifikasi BCB di Indonesia tertuang dalam UU No. 5 tahun 1992 tentang Benda Cagar Budaya (Wuryani dan Purwiyastuti, 2012: 147).

Proses penyadaran kepada masyarakat bahwa desa Balesari memilik potensi yang sangat besar, baik alam, budaya, maupun kearifan lokal sangatlah penting. Pelatihan di sini dibagi menjadi pelatihan bahasa dan pelatihan budaya. Pelatihan bahasa di sini tidak hanya mengajari para penggerak desa wana wisata agar bisa berbahasa inggris yang benar, tetapi juga dilatih bagaimana mengemas potensi-potensi yang dimiliki desa dengan bahasa yang sopan, ramah, dan dapat dipahami oleh mereka para wisatawan asing.

Pelatihan pemasaran budaya juga merupakan hal yang penting karena apabila ada wisatawan asing yang datang, penggerak desa wana wisata ini harus mampu menyuguhkan budaya, cara hidup, dan kearifan lokal yang dimiliki oleh desa karena biasanya wisatawan asing akan tertarik dengan hal tersebut. Selain itu secara bertahap dalam jangka 3 tahun tim Balesari Culture and Language juga akan melakukan konservasi budaya dan bahasa berbasis kearifan lokal yang terdapat di desa Balesari secara bertahap sebagai katalisator yang akan ikut mempercapat laju perkembangan Desa Wana Wisata Balesari.

\section{METODE PENGABDIAN}

Metode dapat diartikan sebagai suatu kerja untuk memahami suatu objek yang menjadi sasaran penelitian. Dalam penelitian sastra, pemilihan metode berkaian erat dengan karakteristik, objek penelitian, masalah, dan tujuan penelitian (Chamamah dalan Jabrohim, 2001: 15). Kaelan (2005: 4) menyatakan bahwa suatu ilmu pengetahuan disebut ilmiah manakala mengembangkan suatu 
model penelitian dengan menggunakan suatu prinsip verifikasi, dan menyangkut objek yang bersifat empiris serta logis.

Metode yang digunakan dalam program ini adalah metode partisipatif, yaitu mengajak masyarakat untuk ikut berpatisipasi dalam melakukan konservasi budaya dan bahasa berbasis kearifan lokal di desa Balesari. Tim melakukan analisi situasi dan kondisi yang terdapat di desa Balesari, melakukan komuniasi dengan para penggerak desa wana wisata balesari, melakukan sarasehan tentang hubungan budaya dan bahasa dalam perkembangan desa wisata, melakukan pelatihan terkait budaya dan bahasa berbasis kearifan lokal, melakukan pendampingan, dan bersama-sama dengan masyarakat melakukan proses konservasi kearifan lokal tersebut. Dalam metode ini ada hubungan timbal balik dari kepada masyarakat, jadi hubungan yang terjalin adalah dua arah dan saling menguntungkan.

Program ini direncanakan berlangsung selama tiga tahun. Tahun pertama berupa studi pendahuluan mengenai potensi budaya dan bahasa berbasis kearifan lokal. Lantas diupayakan analisis budaya lokal yang dapat dimasukkan dalam konservasi budaya sebagi ikon desa wana wisata balesari. Hasil analisis tersebut dipertegas salam sarasehan budaya dan bahasa berbasis kearifan lokal yang dapat meningkatkan laju perkembangan desa wana wiasata balesari. Kemudian dicanangkan pelatihan budaya tari topeng ireng sebagai katalisator laju perkembangan desa wana wisata balesari.

Tahun kedua, diadakan pelatihan bahasa inggris bagi para penggerak desa wana wisata balesari untuk menyambut para wisatawan asing. Disamping juga dilakukan pendampingan upaya pengiklanan, penambahan jaringan internasional, dan komunikasi dengan dengan wisatawan asing.

Tahun ketiga, pendampingan difokuskan pada konservasi budaya dan bahasa secara intensif dan berkelanjutan. Diperkuat dengan pembuatan poster, makalah ilmiah, dan bahan ajar budaya dan bahasa berbasis kearifan lokal desa Balesari.

Program ini dilaksanakan selama 8 kali pertemuan. Selama pertemuan tersebut, para pemuda di desa Balesari akan mendapatkan sosialisasi atau sarasehan dengan mendatangkan pakar budaya dan bahasa. Pakar budaya dan bahasa tersebut akan memberikan wawasan terkait dengan pentingnya budaya dan bahasa bagi perkembangan desa wisata. Selain itu tim Pengabdian Unggulan Universitas juga memberikan pelatihan budaya berupa tari topeng ireng kepada para pamuda di desa Balesari.

Runtutan program yang direncanakan, diharapkan dapat memperkuat dan menanamkan semangat warga setempat untuk menjaga warisan budaya yang 
telah ada. Disamping juga untuk mengenalkan dan mempopulerkan budaya tersebut kepada msayarakat luas.

\section{PEMBAHASAN}

Strategi pemerintah dalam pembangunan kepariwisataan pada program pengembangan destinasi pariwisata difokuskan pada pengembangan desa wisata melalui Program Nasional Pemberdayaan Masyarakat (PNPM) Mandiri. Salah satu konsep pengembangan pariwisata adalah pariwisata berbasis masyarakat atau community-based tourism (CBT) yang bertujan untuk meningkatkan pemberdayaan masyarakat di perdesaan melalui Program Nasional Pemberdayaan Masyarakat (PNPM) Mandiri bidang pariwisata tepatnya melalui Bantuan Desa Wisata. Harapan pemerintah kesejahteraan masyarakat dapat ditingkatkan melalui pembangunan kepariwisataan di desa wisata.

Wisata perdesaan berbasis komunitas adalah pendekatan alternatif dalam industri kepariwisataan yang menitikberatkan pada aspek potensi perdesaan dan potensi masyarakat lokal desa. The World Tourism Organization (2006) memberikan definisi wisata desa sebagai aktivitas wisata yang menawarkan ketenangan desa, jauh dari wisata mainstream perkotaan yang cenderung memiliki intensitas tinggi. Konsep ini memberikan kesempatan kepada turis untuk berinterakjsi secara aktif dengan tuan rumah (warga lokal) dengan hubungan yang otentik. Dalam praktik nyata sering kita jumpai dalam bentuk agrowisata, wisata pertanian, green tourism dan lain sebagainya.

Desa wisata adalah kawasan pedesaan yang menawarkan keseluruhan suasana yang mencerminkan keaslian desa baik dari sosial ekonomi, budaya, dan berbagai potensi unik desa yang telah dikembangkan menjadi komponen wisata seperti pesona alam desanya yang indah, kuliner khas desa, cindera mata, homestay, dan sebaginya. Desa wisata bermakna sebagai kegiatan wisata yang dilakukan pada objek wisata desa. Maka, desa wisata adalah objek dan wisata desa adalah kegiatannya. Keduanya adalah potensi besar yang dimiliki berbagai desa di Indonesia yang saat ini sedang semarak berkembang menjadi potensi peningkatan ekonomi pedesaan.

Tapi tak semudah mendapatkan sebutan desa wisata. Soalnya desa wisata berarti haruslah sebuah desa yang memiliki berbagai aspek yang mendukung desa itu menjadi tujuan wisata yang menarik dengan segala daya dukungnya. Sangat tidak cukup sebuah desa yang hanya memiliki satu dua objek wisata dengan fasilitas seadanya lalu menyebut dirinya sebagai desa wisata.

Desa wisata harus memiliki beberapa sarana dan kondisi pendukung untuk keberlangsungannya. Pertama, aksebility yang baik. Akses menuju desa itu 
haruslah mudah ditempuh berupa jalan aspal halus dan tidak membahayakan. Kalaupun ada bagian jalur yang membahayakan maka harus ada layanan khusus untuk menjamin keselamatan para pengunjung. Seperti jalur cinomati menuju kawasan wisata di dlinggo, bantul. Curam tanjakan di jalur ini membuat warga setempat setiap akhir pekan membentuk tim khusus untuk membantu sepeda motor atau mobil pengunjung yang tidak kuat meniti tanjakan. Dengan demikian pengunjung merasakan diri mereka terlindungi dari sisi keselamatan oleh warga desa wisata.

Kedua, punya objek-objek yang menarik. Ada beragam objek yang bisa dijadikan magnet pariwisata saat ini seperti alam yang menakjubkan, seni budaya, legenda, makanan minuman lokal dan sebagainya. Objek-objek itulah yang akan menjadi magnet utama yang mendatangkan pengunjung.

Ketiga, dukungan seluruh warga desa. Sikap ramah dan tulus menyambut wisatawan adalah syarat utama desa wisata. Hal ini sangat berhubungan dengan kenyamanan dan keamanan wisatawan. Maka proses membangun desa wisata harus melibatkan seluruh warga desa sebagai bagian dari daya tarik desa wisata.

Keempat, keamanan yang terjamin. Jangan sampai ada cerita pengunjung wisata yang dipalak preman atau mengalami kejahatan di desa wisata pada bagian manapun. Sekali hal ini terjadi akan merusak susu sebelanga dan membuat calon pengunjung jadi malas berkunjung ke desa tersebut. Masalah keamanan ini menjadi tanggung jawab seluruh warga desa.

Kelima, tersedianya akomodasi dan telekomunikasi. Jika ada wisatawan yang ingin menginap di sebuah desa wisata seharusnya disediakan homestay yang nyaman dan sarana komunikasi yang lancar. Sehungga hal tersebut akan membuat para wisatawan menjadi nyaman berada di desa wisata.

Desa wisata merupakan sebuah kawasan pedesaan yang memilik keunikan dan karakteristik khusus untuk menjadi destinasi wisata, antara lain: lingkungan bernuansa alami, tradisi dan budaya masih dipegang masyarakat, makanan khas, sistem pertanian dan sistem kekerabatan. Desa wisata sebagai daerah tujuan wisata tertentu perlu ditunjang dengan fasilitas yang memadai bagi para wisatawan. Fasilitas tersebut antara lain: penginapan/ homestay, sehingga wisatawan benar-benar merasakan suasana keseharian pedesaan dengan apa adanya, restoran/ warung makan, arena aktivitas di alam/out bond facility serta berbagai kemudahan bagi wisatawan.

Makin beragamnya pilihan keinginan wisatawan, kesadaran akan pelestarian lingkungan, isu pemanasan global, menjadikan para pelaku pariwisata melirik pada konsep back to nature. Wisata pedesaan sebenarnya suatu bentuk pariwisata minat khusus yang dikemas secara komprehensif sehingga para 
wisatawan dapat berinteraksi secara lengkap baik dengan alam lingkungan maupun dengan masyarakat sekitar termasuk juga budaya dan tradisi di dalamnya.

Wisatwan dapat melihat dan merasakan langsung nilai-nilai kearifan lokal yang masih terasa denyutnya dalam kehidupan masyarakat sehari-hari. Kearifan lokal tersebut seperti: gotong royong, upacara wiwit, sambatan/rewang, kenduri/ selametan, dolanan bocah, kesenian tradisional, ngluku/membajak sawah dengan sapi dan sebagainya. Tentu agar pengunjung desa wisata kerasan, sangat dibutuhkan keterlibatan partisipasi aktif masyarakat lokal agar terjamin keberlangsungan kegiatan pariwisata di desa wisata. Dengan demikian, konsep pariwisata pedesaan menawarkan harapan kehidupan yang lebih baik bagi masyarakat lokal, dengan cara meningkatkan partisipasi aktif masyarakat serta mendorong pelibatan masyarakat dalam setiap kegiatan yang ditujukan kepada pengunjung desa wisata.

Desa wisata merupakan salah satu bentuk penerapan pembangunan pariwisata berbasis masyarakat dan berkelanjutan. Masyarakat lokal berperan penting dalam pengembangan desa wisata karena sumber daya dan keunikan tradisi dan budaya yang melekat pada komunitas tersebut merupakan unsur penggerak utama kegiatan desa wisata (Dewi et al., 2013). Keberhasilan pengembangan desa wisata tergantung pada tingkat penerimaan dan dukungan masyarakat lokal. Pengembangan desa wisata dapat melalui berbagai aspek meliputi pendidikan, pertanian, tata ruang, sosial, dan ekonomi. Secara lebih spesifik, pengembangan desa wisata ditinjau berdasarkan dua aspek, yakni community-based rural tourism (CBRT) dan budaya dan pariwisata perdesaan.

Konsep awal mengenai CBRT adalah konsep community-based tourism (CBT) yang berkembang seiring dengan sustainable development agenda untuk menyeimbangkan faktor pemeliharaan lingkungan hidup dengan manajemen wisata. Lebih mendalam Saarinen, (2006) dan Timothy \& Nyaupane (2009) mengemukakan pentingnya hubungan wisata komunitas dengan pembangunan berkelanjutan Prinsip dari konsep CBT adalah partisipasi publik dan penghargaan hak-hak komunitas lokal. Proses bottom-up dalam perencanaan pembangunan pariwisata menjadi pembeda dengan pendekatan top-down dalam industri pariwisata non-komunitas.

CBRT sebagai domain spesifik wisata berbasis komiunitas dalam lingkup perdesaan menitikberatkan partisipasi publik menjadi acuan pengembangan desa wisata dengan pendekatan analisis stakeholder. Sejalan dengan pendapat dari Laws, Agrusa, Scott, \& Richins, 2011) bahwa: "It is a fundamental precept of tourism research that a wide range of people and organizations are involved in and affected by the 
processes of governing a tourist destination." Pernyataan ini mengandung maksud bahwa usaha wisata melibatkan dan berdampak banyak terhadap masyarakat luas, sehingga memperhatikan kepentingan dan keinginan stakeholder bukan lagi menjadi pilihan akan tetapi sebuah keniscayaan.

Dalam banyak literatur dan studi empiris, faktor budaya menjadi dimensi strategis pengembangan budaya (Laws et al., 2011; Picard, 1990; Suradnya, 2005).Peran budaya menjadi sentral dalam upaya menarik wisatawan terutama wisatawan internasional. Studi yang dilakukan oleh Suradnya (2005) tentang faktor penarik wisatawan di menyatakan bahwa 25\% dari wisatawan yang berkunjung ke Bali, semata-mata tertarik oleh daya tarik budaya yang ditawarkan Bali. Selain itu riset di beberapa desa wisata seperti di Dieng (Raharjana, 2012), Tingkir, Salatiga (Pamulardi, 2006) dan Dusun Ketingan, Yogyakarta (Raharjana, 2005) mengedepankan faktor budaya lokal dalam pengembangan desa wisata.

Hasil riset di luar negeri juga mengindikasikan hal yang serupa bahwa budaya mempunyai hubungan dengan pengembangan pariwisata. Hughes \& Allen (2005) misalnya melakukan studi tentang persepsi tentang promosi wisata budaya bekas negara-negara komunis, rasionalitas mengenai kebijakan tersebut dan meneliti lebih dalam mengenai konsekuensinya. Namun demikian, beberapa studi juga mengingatkan kehati-hatian dalam mengeksploitasi budaya setempat menjadi komoditas wisata. Studi yang dilakukan oleh Cheer, Reeves, \& Laing (2013) di Vanuatu tentang land diving memberikan tensi yang meningkat antara komunitas lokal dengan turis akibat komersialisasi tersebut.

Selain itu perlu diperhatikan juga peran industri kreatif dalam wisata berbasis budaya lokal. Konsep ini memandang perlunya sentuhan kreativitas dalam rangka mengembangkan wisata budaya. Pendapat ini diantaranya diungkapkan oleh Richards, (2010) bahwa kreativitas akan menjadi solusi dari berbagai permasalahan klasik dari wisata budaya yang cenderung berkembang menjadi wisata masal. Secara tegas dia menyebut bahwa "creative tourism as new form of cultural tourism". Selain itu pergeresan tren wisata berbasis budaya juga berimplikasi terhadap hubungan budaya lokal dan industri kreatif yang menghasilkan aktivitas dimana wisata berbasis komunitas diproduksi dari dan untuk turis (Richards, 2011).

Berdasarkan uraian mengenai CBRT dan budaya dan pariwisata perdesaan, Desa Balesari memiliki nilai-nilai unggul yang dapat dijadikan acuan untuk menjadi desa wisata. Desa Balesari memiliki kondisi iklim yang sejuk dan potensial untuk pengembangan berbagai komoditas pertanian meliputi komoditas pangan, komoditas hortikultura, dan komoditas perkebunan. 
Komoditas unggulan di Desa Balesari yang saat ini tengah dikembangkan adalah durian. Durian (Durio zibethinus Murray) merupakan tanaman asli Asia Tenggara yang beriklim tropis basah seperti Indonesia, Thailand dan Malaysia (Ashari, 2004). Komoditas durian menyimpan potensi yang besar sebagai salah satu penggerak ekonomi dari sektor pertanian khususnya hortikultura. Di Indonesia, durian menempati posisi ke-4 produksi buah nasional setelah pisang, jeruk, dan mangga (Santoso dan Priyono, 2015).

Di habitat aslinya, tanaman durian dapat berumur sampai kurang lebih 200 tahun. Tinggi pohon durian berkisar antara 20-40 meter, bahkan dapat mencapai 50 meter (Wiryanta, 2001). Buah durian sudah tidak asing lagi bagi masyarakat Indonesia dan internasional, daging buahnya yang bercitarasa unik dan aromanya yang khas serta bentuk buahnya menjadi ciri utama, tidak salah bilamana durian di dunia internasional dikenal dengan istilah "King of Fruit".

Kegiatan Pengabdian Unggulan Universitas tentang "Balesari Culture And Language (BCL) sebagai Katalisator Desa Wana Wisata Balesari” telah terlaksana dengan baik. Kegiatan dilasanakan dari bulan Juli sampai dengan bulan September 2017. Pelaksanaan kegiatan dimulai pada tanggal 20 Juli 2017; 10 Agustus 2017, 15 Agustus 2017, 22 Agustus 2017, 24 Agustus 2017, 29 Agustus 2017, 31 Agustus 2017; 5 September 2017, 7 September 2017, 12 September 2017, 14 September 2017. Adapun waktu dan jadwal pelaksaan seperti terlihat pada table berikut.

Peserta kegiatan Balesari Culture And Language (BCL) sebagai Katalisator Desa Wana Wisata Balesari adalah para pemuda di desa Balesari yang tergabung dalam kelompok pemuda Balesari. Peserta tersebut mendapatkan pelatihan terkait dengan kebudayaan terutama tari topeng ireng sebagai budaya khas di Magelang.

Dengan adanya pelatihan tersebut harapannya para pemuda desa Balesari mendapatkan pengalaman bagaimana agar mereka bisa menari topeng ireng dengan baik. Selain itu, para pemuda desa Balesari nantinya akan dapat melesatarikan budaya tersebut sehingga terjadi konservasi budaya yang akan berkontribusi terhadap perkembangan desa wana wisata Balesari. Berikut merupakan kegiatan koordinasi program tim Balesari Culture And Language (BCL) sebagai Katalisator Desa Wana Wisata Balesari dengan mas Arwan selaku ketua kelompok pemuda di desa Balesari.

Setelah melakukan koodinasi dengan ketua pemuda desa Balesari, tim Pengabdian Unggulan Universitas membuat persiapan rancangan program. Pertemuan selanjutnya adalah kegiatan pembukaan program yang dilakukan di rumah mbah ayati. Pembukaan ini dihadiri oleh pemuda desa Balesari, Tim 
Pengabdian Unggulan Universitas, Kepala Desa Balesari. Kegiatan ini dimulai pukul 15.00 WIB dengan lancar. Berikut adalah dokumentasi pembukaan program Balesari Culture And Language (BCL) sebagai Katalisator Desa Wana Wisata Balesari.

Setelah acara pembukaan, pertemuan selanjutnya disepakati tetap di rumah mbah ayati. Kegiatan dilaksakan dengan lancar dan dihadiri oleh para pemuda desa Balesari dengan acara sosialisasi program dan analisis local wisdom yang dapat dikembangkan di desa Balesari. Materi ini disampaikan oleh pakar budaya yang mengkritisi bahwa kebudayaan di Indonesia sudah mulai terabaikan. Sebagai generasi penerus bangsa, para pemuda harus tetap melestarikan dan jangan malu dengan budaya sendiri. Berikut adalah dokumentasi dari kegiatan tersebut.

Setelah melakukan sosialisai program, tim Pengabdian Unggulan Universitas juga menggandeng pakar tari topeng ireng (Ulfa Baroroh dan Roikhanatul Jannati) yang sering menarikan tarian tersebut. Mereka sering diundang dalam pementasan tari tradisional maupun modern baik di acara formal maupun non formal. Mereka juga ikut memberikan materi serta melakukan pendampingan dalam praktik tari topeng ireng yang dilakukan oleh peserta yang notabenenya adalah kelompok pemuda desa Balesari. Berikut dokumentasi pada saat mereka memberikan materi terkait tari topeng ireng.

Pertemuan selanjutnya dilakukan selama delapan kali dan diisi dengan materi yang berkaitan dengan tari topeng ireng. Peserta diberikan materi tersebut serta dilatih agar mereka dapat menari topeng ireng. Peserta yang tergabung dalam kelompok pemuda Balesari sangat antusias dalam mengikuti jalannya pelatihan. Mereka mengikuti materi dan praktik melakukan tari topeng ireng dengan totalitas. Hal tersebut tercermin dalam dokumentasi yang dilakukan berikut ini.

Setelah semua materi yang berkaitan dengan budaya dan tari topeng ireng diberikan, para pemuda desa Balesari mempraktikkan tarian tersebut. Mereka memperagakan tarian topeng ireng dengan sangat antusias. Tampak para pemuda menikmati tarian topeng ireng yang diiringi musik yang merdu.

Suatu ilmu pengetahuan akan senantiasa berkembang mengikuti situasi dan kondisi yang terdapat di dalam masyarakat. Begitu juga dengan program Pengabdian Unggulan Universitas yang akan dikembangkan. Rencana pengembangan tersebut berupa memberikan pembekalan terkait dengan Iklan berbasis TIK. Dengan memberikan pembekalan iklan berbasis TIK harapannya para kelompok pemuda desa Balesari dapat mempopulerkan desa wana wisata 
Balesari agar ke depan lebih banyak lagi khalayak yang akan datang dan berkunjung ke desa wana wisata tersebut.

Juga dengan melakukan pendampingan konservasi budaya dan bahasa. Dengan memberikan pendampingan kepada kelompok pemuda desa Balesari, maka konservasi budaya dan bahasa di desa tersebut akan dapat berjalan dengan lancar. Apalagi pemerintah desa sangat mendukung program ini, nantinya konservasi budaya dan bahasa akan menjadi salah satu katalisator bagi terbentuknya desa wana wisata Balesari yang indah.

\section{PENUTUP}

Program Pengabdian Unggulan Universitas dengan judul "Balesari Culture And Language (BCL) sebagai Katalisator Desa Wana Wisata Balesari" tahun pertama berjalan dengan lancar. Para peserta yang berasal dari kelompok pemuda desa Balesari mengikuti kegiatan dengan antusias dan senang. Kegiatan tahun pertama ini dilakukan untuk memberikan pengetahuan dan keterampilan dalam hal tari topeng ireng kepada para pemuda desa Balesari. Kegiatan ini dilakukan selama 11 kali pertemuan yang dilaksanakan di rumah mbah ayati. Pelaksanaan kegiatan dimulai pada tanggal 20 Juli 2017; 10 Agustus 2017, 15 Agustus 2017, 22 Agustus 2017, 24 Agustus 2017, 29 Agustus 2017, 31 Agustus 2017; 5 September 2017, 7 September 2017, 12 September 2017, 14 September 2017. Pelaksanaan Pengabdian Unggulan Universitas tidak akan berjalan dengan lancar tanpa adanya bantuan dari pemerintah desa Balesari yang telah mensuport kegiatan ini dan memberikan bantuan moral kepada tim Pengabdian Unggulan Universitas. Selain itu, mas Arwan sebagai ketua pemuda di desa Balesari pun selalu membantu jalannya kegiatan dengan menggerakkan para pemuda dan ikut menyaiapkan tempat serta sarana yang dibutuhkan oleh tim Pengabdian Unggulan Universitas.

Tahun pertama Pengabdian Unggulan Universitas berjalan dengan lancar. Harapannya tahun kedua juga akan berjalan dengan lancar sehingga proses konservasi budaya dan bahasa yang terdapat di desa Balesari dapat berjalan dengan lancar. Dengan adanya konservasi budaya dan bahasa tersebut, maka desa wana wisata Balesari akan menjadi salah satu destinasi wisata yang tidak hanya menawarkan romansa pemandangan alam, tetapi juga memberikan suguhan estetis bagi wisatawan baik domestik maupun asing. 


\section{DAFTAR PUSTAKA}

Chamamah-Soeratno, Siti. 2003. "Resepsi Sastra Teori dan Penerapannya" dalam Jabrohim (ed). Metodologi Penelitian Sastra. Yogyakarta: PT. Anindita Graha Widya.

Kaelan. 2005. Metode Penelitian Kualitatif Bidang Filsafat. Yogyakarta: Penerbit Paradigma.

Karim, Abuya Busro. Pariwisata; Antara Tuntutan Industri dan Kearifan Lokal. Jurnal Karsa Volume 18 Nomer 22010

Pujiyanti, Nunik, Eksistensi Tari Topeng Ireng sebagai Pemenuhan Kebutuhan Estetik Masyarakat Pandesari Parakan Temanggung, Jurnal Catharsis Volume 2 Nomor 12013.

Maleong, Lexi J. 1989. Metodologi Penelitian Kualitatif. Bandung: CV Remadja Karya.

Mosse, Julia Cleves. 1996. Gender \& Pembangunan. Yogyakarta: Pustaka Pelajar dan Rifka Annisa Women's Crisis Centre.

Wuryani, Emy dan Wahyu Purwiyastuti, Menumbuhkan Peran Serta Masyarakat dalam Melestarikan Kebudayaan dan Benda Cagar Budaya melalui Pemberdayaan Masyarakat di Kawasan Wisata Dusun Ceto, Jurnal Satya Widya Volume 28 Nomor 2012. 